\title{
Pectoral Lymph Node
}

National Cancer Institute

\section{Source}

National Cancer Institute. Pectoral Lymph Node. NCI Thesaurus. Code C120322.

An axillary lymph node located along the lower edge of the pectoralis minor. 